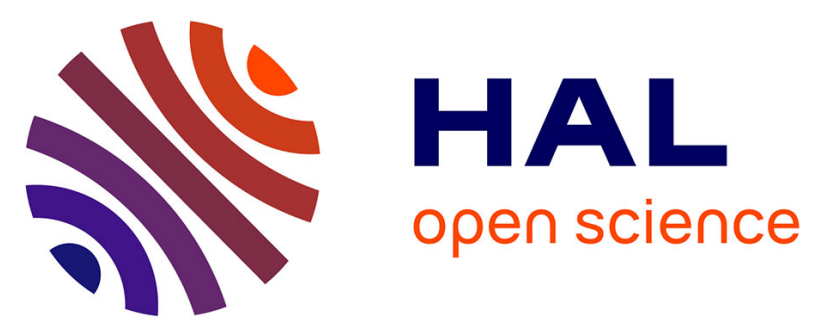

\title{
See how they fly! Some considerations on symbolic transfers and territories at the end of upper paleolithic
}

Elena Man-Estier, Patrick Paillet

\section{To cite this version:}

Elena Man-Estier, Patrick Paillet. See how they fly! Some considerations on symbolic transfers and territories at the end of upper paleolithic. Quaternary International, 2019, 503, pp.248-253. 10.1016/j.quaint.2017.12.041 . hal-01875405

HAL Id: hal-01875405

https://hal-univ-rennes1.archives-ouvertes.fr/hal-01875405

Submitted on 17 Sep 2018

HAL is a multi-disciplinary open access archive for the deposit and dissemination of scientific research documents, whether they are published or not. The documents may come from teaching and research institutions in France or abroad, or from public or private research centers.
L'archive ouverte pluridisciplinaire HAL, est destinée au dépôt et à la diffusion de documents scientifiques de niveau recherche, publiés ou non, émanant des établissements d'enseignement et de recherche français ou étrangers, des laboratoires publics ou privés. 
See how they fly! Some considerations on symbolic transfers and territories at the end of Upper Paleolithic

Man-Estier E. ${ }^{a}$ et Paillet P. ${ }^{b}$

a DRAC Bretagne, Service régional de l'Archéologie and UMR 6566 CReAAH University of Rennes I, France

b Muséum national d'Histoire naturelle, Département Homme-Environnement, UMR 7194 Histoire naturelle de l'Homme préhistorique, Musée de l'Homme, Paris, France

\section{Abstract}

Paleolithic portable art is constitutive of social and cultural identities, as images create a link between territories and men. Therefore, the study of some symbols can lead to a better understanding of the status and the complexity of symbolic territories. In this paper we present the history of diffusion of two symbols from Upper Magdalenian, macrocephalic horses and complex signs coming from a specific site. After a theoretical reflections on the status of symbol, we are considering what criteria should be taken into account for defining each of these symbols and understand how they have diffused - or not - in their immediate or more distant environment. The focus upon designs shareable but that haven't been transferred around suggests new perspectives for thinking the investment of human groups in their symbolic territory, through their artistic production. Therefore, we aim at demonstrating that immobility of images should, as their mobility, be taken in account in the cultural geography of the Upper palaeolithic.

\section{Key-words}

Upper Palaeolithic, Magdalenian, Portable art, Symbols

\section{Introduction}

Natural spaces and landscapes constitute a general structure of territories culturally transformed by humans. The anthropization of natural lands is being realized according to two complementary dynamics, opposing fixation and mobility of human groups (Vialou 2005). Nature is being sedentarized, especially places of habitat, and is lived and certainly thought differently than the traveled nature, being considered as a network of economy, acquisition, subsistence or exchanges itineraries. The visual appropriation of landscapes by parietal or portable images is carried out according to the same processes. Thus, within the space of Palaeolithic territories, we can dissociate or differentiate the physical immobilization of parietal and rock-art symbols and the mobility of art objects, perhaps together with the symbols they convey. Both are constitutive of social and cultural identities, as images create a link between territories and men and exert on these territories a unique and powerful cultural influence and mediation. Images transcend the primary economic relationship established by men with landscapes. Therefore we consider that sharing and exchange of graphic symbols from one human group to another provides valuable information about social relations through distance. Symbols constitute a mean of clarifying the real nature of networks of exchanges, offering to go beyond the material or technological dimension and highlighting possible fluctuations at the end of the Late Glacial (circa $14000 \mathrm{yBP}$ ). Portable artworks are powerful cultural markers that also fortify thinking on the territorial influence of symbols and, more broadly, on the frames of human and social geographies they help to define. Through the notion of symbolic territory, wondering upon new relations to the daily physical, economic and social space is led possible. Last, images question 
the modalities of their own diffusion together with phenomena of borrowing, transfer or symbolic convergence, rules governing inter-group exchanges and social relations within groups. Images thus play an essential role in cultural identification and characterization.

\section{Background}

If we wish to apply the notion of "symbol" to prehistoric graphic evidences, which are distant and often not very explicit, it is necessary to have a semantic discussion on this term whose definition could be complex. In linguistics, the term "sign" is generally preferred to "symbol". This word is very early defined (de Saussure, 1912) as an association of a signifier (the form) and a signified (the background, the meaning). In semiotics, a science dedicated to the analysis of signs, the term takes on a different dimension. In general, visual communication that it carries is recognized as a multiparty association of the signifier (the image in its materiality), a referee or "object" (Peirce, c. 1894) coming from the real or imaginary world (the model) and the signified (the meaning). Several authors have sought to define with precision the functioning of this relation (e.g. Peirce, 1895, Morris, 1964, Sonesson, 1988). The term "symbol" can then be distinguished from the sign, corresponding either to the case of a motivated relation between image and sense, or on the contrary to the case of an arbitrary sign (Peirce, c. 1894). According to the definition of $U$. Eco (1988), already applied to prehistoric archeology by M.J. Rossano (2010) and specifically on prehistoric art by G. Sauvet (1990), we propose to consider that symbol exists as soon as a specific relationship exists, between an object - whether coming from the real world or part of emotional world of the author, called the referee, a graphic demonstration - the signifier - and a meaning known by the transmitter and surely shared with others persons - the signified. The existence of shared graphic conventions, through perceptual codes or striking characteristics, being described as traits of recognition (Eco, 1988) or "identification keys" (Man-Estier, 2011, Man -Estier et Paillet, 2013) allows the symbol in question to being appropriated by the group. Thus, one could propose that a paleolithic representation of Deer becomes a "symbol" when some criteria (anatomical, ethological, etc.) of cervids are present and are graphically represented in a particular way. The hypothesis of existence of such symbol seems therefore conceivable only in a case of sufficiently extended and coherent corpus. We also propose to take some distance with the distinction between figurative and abstract, usually prevailing in the study of prehistoric art (Sauvet, 1990). Indeed, it seems to us that a "figurative" representation, that is to say referring to a referent coming from the author's environment, can be fundamentally conventional and connotative, just as much as a geometric or abstract pattern. With no doubt it may have had a different meaning than the denoted information offered to view. Moving away from the object to which it refers and from its material dimension, the image becomes a symbol, inaccessible to our understanding. Processing is the same for rock art symbol, that are able to travel as much as portable artworks, despite their fixed conditions (see for instance Bourdier, 2013 ; Bourdier and Pinçon, 2016). The message may become even more confusing when the image is surrounded by a multitude of meanings and connotations. Finally how can one attest that a bison image, especially if it gathers several original production standards, really meant "bison" in the mind of its creator?

\section{Goals}


From this general definition of "symbol", and by examining two types of conventional and standardized art production, specific of the end of the Upper Palaeolithic (Upper Magdalenian) in the great south-west of France, we wish to evaluate the territorial dynamics of a figurative image (macrocephalic horses) and an apparently non-figurative design (Rochereil complex patterns). These two symbols have been created by Magdalenian groups which have in common, besides their geographical implantation, some raw materials, some lithic and osseous productions and certain know-how. The symbolic material is being analyzed and relocated within the framework of the phenomena of mobility, fixation, diffusion or transfers that regulate visual communication at a territorial scale. Hypothesis on the question of symbolic territories have already been proposed, often based on the existence of codes of representations, morphological criteria or shared themes (for instance Bahn, 1982 ; Feruglio, 2014 ; Fortea Perez et al., 2004; Fritz et al. 2007 ; Fuentes, 2013 ; Sauvet 2014 ; Welté and Lambert, 2004). We can mention specifically studies on front views animals (Sauvet and al. 2008) or feminine schematic figures (Aujoulat and Feruglio 2001) at the end of Magdalenian.

\section{Materials}

The corpus studied is located in the actual territory of Périgord, which corresponds more or less to the geographical limits of the administrative department of the Dordogne (South-west of France). The chronology is restricted to the end of the Upper Palaeolithic and more precisely the Upper Magdalenian. It is coming from several open air sites along the valleys of Vézère and Dordogne with an epicenter around the rockshelters of La Madeleine and Laugerie-Basse, and the Isle and Dronne valleys, in the northern part of the region, around the small cave of Rochereil (figure 1). The first of the symbols we have chosen to study is the macrocephalic horse, sometimes referred to as "hypertrophied" or even "barygnath", that is to say, bearing heavy jaws. It seems we can propose to link this pattern to the sequence of the Late Glacial such as it is known within the site of La Madeleine (layer F, dated between 16236 and 13991 years cal BP (D'Errico et al. 2011 and Bouvier, 1977)). In the current state of knowledge, there are 108 representations of macrocephalic horses, spread over 42 objects, and coming from 9 sites in Dordogne and Gironde: La Madeleine, Laugerie-Basse, Limeuil, Le Soucy, le Morin, Raymonden, Jolivet, Rochereil, La Peyzie (Appelaniz, 1990 ; Deffarge et al. 1975 ; Man-Estier and Paillet, 2014, Paillet, 2014a, Sieveking, 1987). Three more distant sites (Montastruc and Fontalès in the Tarn-etGaronne and Mas-d'Azil in Ariège) offered other horses (4 at Montastruc, 5 at Fontalès and 3 at Mas d'Azil) evoking the macrocephalic representations, but whose formal characteristics and technical choices do not quite correspond to the referential corpus (Appelaniz 1990, Aujoulat and Feruglio, 2011). The second type of representations we are willing to study comes from the little cave of Rochereil (GrandBrassac, Dordogne). The site was excavated in the first half of the 20th century (Jude, 1960) and since 2011 has been subject of a Collective Research Project (Paillet 2014b ; Paillet and Man-Estier 2013, 2014) aiming at a new evaluation of ancient series (lithic and osseous material), fauna and numerous nonutilitarian productions. The corpus gathers today nearly 270 portable art objects. The archeostratigraphic context of these productions (layer A of the old and new Magdalenian superior) is contemporary with layer 
5. Results

\section{1. macrocephalic horses}

This conventional representation (figure 2 ) is essentially, but not exclusively, concerning horses. Cervids can be found represented with the help of the same formal code. It is characterized by a disproportionate treatment of the animal's forms, mainly its head whose size is exaggerated. It owes its name to this artifact of recognition, even if the morphotype fluctuates, in a certain graphic and expressive continuity, between more or less realistic representations and others that are frankly schematic. Some are also incomplete (heads, anterior part of bodies).

Considering these formal characteristics, J.-M. Appelaniz (1990) suggests to retain in the macrocephalic corpus only figures which head's length scores at least $1 / 4$ of that of the body. We can add that some extremely dilated heads occupy up to $1 / 3$ of the total length. From this ideal morphotype, macrocephalic horse assumes other formal characteristics. The body is angular, giving the impression of being stretched. It is often completed by stiff and unfinished anterior and posterior limbs, figured alone or in contiguous pairs, frequently stretched backwards. They dynamically project the animal forward, thus breaking with the stiffness of the legs. When present, the tail is long, narrow and pointed. Rarely, it is completed with a brush or presented disheveled (Lartet and Christy 1865-1875). It is however always detached from the buttock and placed diagonally, in extension. Other technical, graphic and anatomical details complete the typical portrait of the macrocephalic horse. The heads have an angular appearance at the level of the muzzle and the cheek. Their silhouette is polygonal. Frequently, nostril, mouth, eye, and sometimes rock at the back of the latter, as well as the zygomatic, are well indicated. The chin and the cheek are heavy, which underlines the pre-cited "heavy jaw" character. According to E. Lartet and H. Christy, the heads of these animals are heavy and "sounded", that is to say stiff (Lartet and Christy, 1865-1875). On the neckline, the jugular is firmly underlined. Ribs are sometimes indicated by oblique incisions along the back. The mane, bearing an "English style" (Lartet and Christy 1865-1875), frequently stands as a helmet and / or is being separated from the neck by a deep incision. Individuals wear shoulder lines; others have features that mark the belly and the kidneys.

From a technical point of view, contours and details are almost systematically obtained by deep incisions of asymmetric profile. Animal then appears on its medium in a slight or raised relief. Finally, except when mediums are fragmentary, the macrocephalic animals are rarely isolated. They are most often organized in a row of two to five individuals, never opposed. There isn't indication of any particular ethological character. In their individual and collective expression they seem to strictly conform to the constraints of the mediums, on one or two faces of the objects (spear points, chisels). On bored sticks, both faces aren't systematically decorated but the horses are also arranged in file and often occupy the entire length of the body of the object, sometimes even integrating the hole. The macrocephalic horses are thus framed in all available fields. They are even sometimes so reduced, especially on chopsticks, that they lose anatomical details like legs or top of the neckline.

This ideal portrait of the macrocephalic horse is then an animal whose fore-hand is hypertrophied, and certainly not a "degenerate" figure (Breuil, 1905, 1907). The symbol, with its internal details meets strict formal and aesthetic standards, which seem not to have been questioned during production's period and within its geographical area of influence (Rivero and Sauvet, 2014). 
Another interesting aspect of the subject is that of medium invested by these representations. They are almost always made of reindeer antlers, on beam or on chopsticks. The corpus recorded 29 spearpoints, 3 chisels and 10 bored sticks (Appellaniz, 1990; Man-Estier and Paillet, 2014). It seems that the medium, limited to a small number of possibilities offered to the artist, plays a role in the composition of the symbolic concept of "macrocephalic horse".

The conventional model of the horse seems to be coming from an artistic production limited in the time of the old and new Upper Magdalenian. According to the research conducted by J.-M. Appelaniz (1990), this design could find its origin in La Madeleine that gathers the main quantity of material. Moreover, on the basis of an iconographic analysis backed by statistical methods, this researcher has tried to objectify his method of determining the author of this symbol by applying it to what he supposes to be the "school" of the engravers of the Madeleine. This concept of "school" or "workshop" applied to the production of macrocephalic horses is important since it mobilizes other notions such as learning, acquiring and transmitting know-how.

\subsection{Rochereil complex signs}

The observed mobility and the apparent success encountered by macrocephalic horses in southwestern France can be contrasted with the apparent fixation of another system of representation composed of certain structured and original motifs, placed in the blur limits of the figurative and non-figurative, coming from Rochereil (figure 3).

Throughout this second corpus we have been able to individualize a large number of original representations, rather geometric in appearance, structured from oval or rhombus forms. In the body of the pattern, or at its periphery, are aggregated (according to the definition of Sauvet, 1990), through very varied graphic formulas, internal fills or excrescences. These representations have been interpreted successively as "degenerations" of animal figures (Breuil 1905, 1907), phytomorphic or foliaceous motifs, or even animals seen from the front (Man-Estier et al., 2016; Paillet and Man-Estier, 2016). Out of 501 graphic entities, spread over 267 decorated objects (mainly on osseous material), we have identified more than 400 motifs answering the same general set. Their common characteristic lies in the rigorous production standard that seems to govern its composition. They are elaborated from a geometrical body (parenthesis, oval, lozenge ...), endowed with internal graphic elements (lines, unidirectional hatchings, cluster of forms), and external elements concatenated. The latter are generally organized in the form of one, two or three excrescences, juxtaposed with the main body and placed in its prolongation. They can thus be interpreted, according to their shape and the sense of reading given to the image, as horns, legs or even fins seen in front view. Several patterns are also prolonged by a curved line, located in the median axis of the body and which delimits symmetrically the space. We have estimated at more than 4000 the possible combinations of these different elements, to which we must add the innumerable juxtapositions of the motives between them.

The types of mediums invested are less limited than in the previous example. They correspond to a majority of tools or weapons on reindeer antlers (115 objects) (such as spear points, chisels, barbed points), but other media are also concerned. We have counted 4 bored sticks, an ellipse, as well as raw antlers or waste (24). Bones material is also numerous (105 of which only 9 tools). Despite this variability of the mediums, complexity of representation and its relatively coherent formal architecture make us 
consider these images, in their unity and their variability, as one of these "shareable" symbols, according to the definition proposed above.

\section{Discussion}

Therefore we can wonder about the differences of diffusion of these two symbols. Concerning the last, it is indeed very surprising not to find similar patterns within the contemporary and geographically close sites. With the exception of two objects, one from La Madeleine (Dordogne) and the other from Murat (Lot), our revisions of the classical series did not allow us to identify formal equivalents. Despite an intense and standardized production, even remarkable if it is linked with the site's modest dimensions, the symbol invented at Rochereil didn't spread and doesn't seem to have been shared or borrowed, except may be in a strict domestic context. Its formal and certainly symbolic immobilization, which reflects a form of local idiosyncrasy, is in radical opposition with the extreme mobility of other symbols such as the macrocephalic horse, also existing in Rochereil.

As we mentioned above, macrocephalic horses are also known further away, in Quercy (Tarn valley) and in the Pyrenean foothills (Appelaniz, 1990). But the small number of these documents (12 graphic entities on 3 objects) and especially the modes of representation, quite different from the main corpus (rounded heads, abundant coat, bone mediums...), could carry an hypothesis of diffusion through a new space, distinct from the usually frequented one, by the group at the initiative of the symbol.

In this context, the evolution of image allows us to consider that the transfer of the image and its referent has been accompanied by a loss of its meaning, or at least a loss of the iconographic convention linking the meaning to the image. Independently of this somewhat anecdotal aspect, the appearance of the symbol "macrocephalic horse on reindeer wood", mainly along the valleys of the Dordogne and Vézère can appear as a rather successful example of diffusion. But it wouldn't be silly to take here in consideration also the own will of the producers of the symbol, that is to say the artists themselves but perhaps also the "decision-makers", and therefore considering, after A. Gell (1998) the artwork as a media of social agency. This would allow us to a better understanding of the actual status of this dissemination and its role at the time. Why did some people want to produce similar objects, decorated with the same pattern? Why and how has this symbol been transmitted to other groups? What king of value was associated with it? Even if the answers to these questions are not touchable, we can simply repeat that the mobility of this symbol, which retains an excellent homogeneity despite its travels, is a strong testimony to the existence of cultural territories such as we seek to apprehend.

\section{Conclusion}

Through these two examples is being constructed the image of a complex symbolic territory at the end of the Magdalenian. The existence of social exchanges at medium distance along the valleys of the Vézère and the Dordogne seems coherent with the spread of the symbol of the "macrocephalic horse". This mobility of the image can be perceived as a vector of unification of systems of representation, each site retaining its originality.

$$
\text { In Rochereil, the coexistence of a symbol coming from elsewhere, well diffused, together with an original }
$$
endogenous symbol, prompts us to question the functioning of the regional cultural network in the Upper Magdalenian. Without being able to attest that this is a failure of diffusion, its absence elsewhere than on 
1 the site princeps prompts us to reconsider our way of perceiving the exchanges of content and production.

2 Only systematic revision of corpus and indexation on extremely fine time scales will be able to remove

3 highlight reality of the areas traveled by symbols, by men, and by ideas. Territory, both symbolic or natural, 4 seems now to need to be perceived as much through the mobility of groups that through the apparent 5 sedentariness that emerges from some productions, at least on the short time scale of a man's life. 
References

1. Appelaniz J.M., 1990. Modèle d'analyse d'une école dans l'iconographie mobilière paléolithique : l'école des graveurs de chevaux hypertrophiés de la Madeleine. In : Clottes J. dir. L'art des objets au Paléolithique, les voies de la recherche, t.2, Actes des colloques de la Direction du Patrimoine, Colloque de Foix-Mas d'Azil, 16-21 novembre 1987, Ministère de la Culture, p. 105-138

2. Aujoulat N. and Feruglio V. 2011. L'Art pariétal et mobilier du Magdalénien supérieur et de l'Azilien à l'échelon européen, in. Coll., Mille et une femmes de la fin des temps glaciaires, catalogue d'exposition,

9 Paris, Réunion des Musées nationaux.

10 3. Bahn P. G. 1982, « inter-site and Inter-regional links during the Upper Palaeolithic : the Pyrenean

11 evidence », Oxford journal of Archaeology, Vol 1, Issue 3, November 1982, pp.247-268.

12 4. Bourdier C., 2013. Rock Art and Social Geography in the Upper Palaeolithic. Contribution to the Socio13 Cultural Function of the Roc-aux-Sorciers Rock-Shelter (Angles-sur-l'Anglin, France) from the Viewpoint of its Sculpted Frieze. Journal of Anthropological Archaeology, 32, p. 368-382.

15 5. Bourdier C. and Pinçon G., 2016. Norme et individualité au Roc-aux-Sorciers (Vienne, France) : approche des « mains » du registre animalier au travers de la forme, In Groenen M. et Groenen M.-C. (ed.), Styles, techniques et expression graphique dans l'art sur paroi rocheuse, Actes du XVIle congrès de I'UISPP, Burgos, 1-7 sept. 2014, session A11d. BAR International Series, Liège, p. 17-35.

6. Bouvier J.-M., 1977, Un gisement préhistorique, La Madeleine, éditions Pierre Fanlac, Périgueux.

7. Breuil $H_{\text {., }}$ 1905. La dégénérescence des figures d'animaux en motifs ornementaux à l'époque du renne. Comptes-rendus de l'Académie des Inscriptions et Belles Lettres, 1905, p.105-120.

8. Breuil H., 1907. Exemples de figures dégénérées et stylisées à l'époque du renne. Comptes-rendus du XIII $\square$ Congrès d'Anthropologie et d'Archéologie préhistoriques, Monaco, 1906, p.394-403.

9. Deffarge R., Laurent P. et Sonneville-Bordes D. (de), 1975. Art mobilier du Magdalénien supérieur de l'abri Morin à Pessac-sur-Dordogne (Gironde). Gallia-Préhistoire, Tome 18, n¹, p.1-64. 10. D'Errico F., Banks W., Vanhaeren M., Laroulandie V. and Langlais M., 2011, "Pacea Geo-referenced Radiocarbon database", Paleoanthropology, vol 1, pp. 1-12 and supplementary materials 1. 11. Eco U., 1988. Le signe : Histoire et analyse d'un concept, Editions Labor, 220 p.

12. Feruglio V., 2014. L'art mobilier magdalénien de la région des Eyzies : sur la piste des liens sociaux en Europe occidentale, in., coll. Grands sites d'art magdalénien. La Madeleine et Laugerie-Basse, il y a 15000 ans, Catalogue d'exposition, edition of Réunion des Musées nationaux, Paris, pp. 68-71. pariétal paléolithique à l'épreuve du style et du carbone-14, In. M. Otte (ed.), La spiritualité, ERAUL 106, Liège décembre 2003, pp. 163 - 176 14. Fritz, C.; Tosello G.; Sauvet G. (2007). Groupes ethniques, territoires, échanges : la « notion de frontière » dans l'art magdalénien. In N. Cazals, J. Gonzalez Urquijo y X. Terradas (dir.) Frontières naturelles, frontières culturelles dans les Pyrénées préhistoriques. Actes du colloque de Tarascon-sur-Ariège, 10-12 mars 2004, PubliCan-ediciones de la Universidad de Cantabria, p. 165-181 15. Fuentes O., 2013. The depiction of the individual in prehistory : human representatiobn in Magdalenien societes. In. Antiquity, vol. 87, n²28, p. 985-1000.

41 16. Gell A., 1998, Art and Agency: An Anthropological Theory. Oxford: Clarendon. 
17. Jude P.-E., 1960. La Grotte de Rochereil. Station magdalénienne et azilienne. Archives de l'I.P.H., Mémoire $\mathrm{n}^{\circ} 30$, Paris, 74 pages.

18. Lartet E. and Christy H., 1865-1875. Reliquiae Aquitanicae, being contributions to the archaeology and Palaeontology of Perigord and the adjoining provinces of Southern France, Londres, Williams and Norgate (H. Baillière), 1865-1875, In- $8^{\circ}, 506 \mathrm{p}$.

19. Mallye J.-B., Boudadi-Maligne M., Langlais M. and Laroulandie V., 2014. Rochereil et son cadre radiocarbone, synthèse des datations obtenues, in. Paillet, dir. Peuplements et cultures à la fin du Tardiglaciaire dans le Nord du Périgord, rapport final de synthèse 2012-2014, Direction régionale des affaires culturelles, Bordeaux, pp. 33-36.

20. Man-Estier, 2011, Les Ursidés au naturel et au figuré pendant la préhistoire, E.R.A.U.L. №127, Liège, 125 p., CD-ROM.

21. Man-Estier E. and Paillet $P$;, 2013. Réflexions sur le réalisme et le naturalisme dans l'art préhistorique. L'exemple de l'ours, in M. GROENEN (dir.) Expressions esthétiques et comportements techniques au Paléolithique, Actes des sessions thématiques 36 et 37, XVlème congrès UISPP- SAB, 4-10 septembre 2011, Florianópolis, Brésil, BAR International Series, 2496, vol.3, Archaeopress, Oxford, p. 73-86.

22. Man-Estier E. and Paillet P., 2014. Regards croisés sur l'art magdalénien de deux grands sites, in., coll. Grands sites d'art magdalénien. La Madeleine et Laugerie-Basse, il y a 15000 ans, Catalogue d'exposition, edition of Réunion des Musées nationaux, Paris, pp. 62-67.

23. Man-Estier E., Paillet P., Rémy D., Vercoutère C., with collaboration of Bonnet-Jacquement P., BoudadiMaligne M., Langlais M., Laroulandie V., Mallye J.-B., Rigaud S., 2016. Supports et représentations dans l'art mobilier magdalénien de Rochereil (Grand-Brassac, Dordogne, France), in. Cleyet-Merle J.-J., 20. Geneste J.-M., Man-Estier E. (ed) L'art au quotidien - Objets ornés du Paléolithique supérieur, Actes du colloque international, Les Eyzies-de-Tayac, 16-20 juin 2014, PALEO, numéro spécial, 2016.

24. Morris C.W., 1964. Signification and Significance. A study of the relations of signs and values. Cambridge, MIT Press.

25. Paillet P., 2014a. L'art des objets de la Préhistoire. Laugerie-Basse et la collection du marquis Paul de Vibraye au Muséum national d'Histoire naturelle, Éditions Errance, Arles, 2014, 216 p.

26. Paillet P., 2014b. Men and cultures at the end of the late Ice age in the north of Perigord: continuities and ruptures. Rock Art Studies, Volume 1, Concept, Methodology, Context, Documentation and Conservation, International Conference on Rock Art, 06-13 December, 2012, Understanding Rock Art in Context, IGNCA Series - 10, Indira Gandhi National Centre For The Arts, New Delhi, Edited by Bansi Lal Malla, Aryan Books International, p.135-150.

27. Paillet P. and Man-Estier E., 2013. Rochereil et l'art magdalénien de la fin du Tardiglaciaire dans le Nord du Périgord. Actes de la session 36, XVI Congrès UISPP et SAB, septembre 2011, Florianopolis, Brésil, British Archaeological Reports, p.7-36.

28. Paillet P. and Man-Estier E., 2014. La grotte de Rochereil à Grand-Brassac (Dordogne) : de l'art de faire parler les déblais et les archives. Mélanges Alain Roussot, Préhistoire du Sud-Ouest, n²2-2014-1 et 2, p. 121-132

29. Paillet P. and Man-Estier E., 2016. Langage de signes et communication graphique à la fin du Magdalénien. L'art de Rochereil (Grand-Brassac), de l'abri Mège et de la Mairie (Teyjat, Dordogne), in. 
scientifiques), 2016.

2 30. Peirce, C.S., circa 1894. What Is a Sign?, Published in part in CP 2.281, 285, and 297-302, and in full in 3 EP 2:4-10, Peirce Edition Project (online edition).

4 31. Rivero $O$ and Sauvet G., 2014. Defining Magdalenian cultural groups in Franco-Cantabria by the formal 5 analysis of portable artworks, Antiquity, 88, no 339, march 2014.

6 32. Rossano M. J., 2010. Making friends, making tools, making symbols, Current Anthropology, vol. 51 No

7 S1, Working memory : beyong language and symbolism, june 2010.

8 33. Sauvet G., 1990. Les signes dans l'art mobilier, in : Clottes J. dir. L'art des objets au Paléolithique, les

9 voies de la recherche, t.2, Actes des colloques de la Direction du Patrimoine, Colloque de Foix-Mas d'Azil, 10 16-21 novembre 1987, Ministère de la Culture, pp. 83-99.

11 34. Sauvet G., Fortea Perez J., Fritz C.and Tosello G., 2008. Crónica de los intercambios entre los grupos 12 humanos paleolíticos. La contribución del arte para el periodo 20000-12000 años BP, Zephyrus, vol. 61 (1), 13 pp. 35-61

14 35. Sauvet G., 2014. Histoire de chasseurs. Chronique des temps paléolithiques ; in. Soleded Corchon, M. 15 and Menendez, M. ed., Cien años de arte rupestre paleolitico, Edition Universidad de Salamanca, Spain, 16 pp. $15-30$

17 36. Sieveking A., 1987. A catalogue of Palaeolithic art in the British Museum? London, The British museum 18 Press.

19 37. Sonesson G., 1988. Methods and models in pictorials semiotics, Reports of the semiotics project, Lund 20 University.

21 38. Vialou D., 2005. Territoires, sédentarités et mobilités, in. Vialou D., Renault-Miskovsky J, Patou-Mathis 22 M., (eds.), Comportements des hommes du Paléolithique moyen et supérieur en Europe. Territoires et 23 Milieux, ERAUL 111, Liège, $250 \mathrm{p}$

24 39. Welté A.-C. and Lambert G.-N., 2004. «L'art mobilier du Magdalénien supérieur des sites de la vallée de 25 l'Aveyron et d'Europe centrale : relations et/ou convergences ? ", in. Lejeune M. and Welté A.-C., dir., L'art 26 du Paléolithique supérieur en Europe occidentale, Actes du XIVè congrès de l'UISPP, Liège, 2-8 septembre 27 2001, pp.239-248, Liège, Eraul n¹07, Université de Liège. 
1 Figures

2

3 Figure 1 - map of thes site mentionned in the text (CAD E. Man-Estier). 1.Abri Morin, 2.Le Soucy, 3.Limeuil,

4 4. Laugerie-Basse, 5. La Madeleine, 6. Jolivet, 7. Raymonden, 8. La Peyzie, 9. Rochereil. 5

6 Figure 2 - macrocephalic horses exemples from La Madeleine (up) and Rochereil (bottom), pictures trustees 7 of the British Museum (up), MNHN - JCDomenech (bottom).

8

9 Figure 3 - complex signs from Rochereil, tracings $P$. Paillet.

10

11 Figure 3 - complex signs from Rochereil, tracings P. Paillet. 


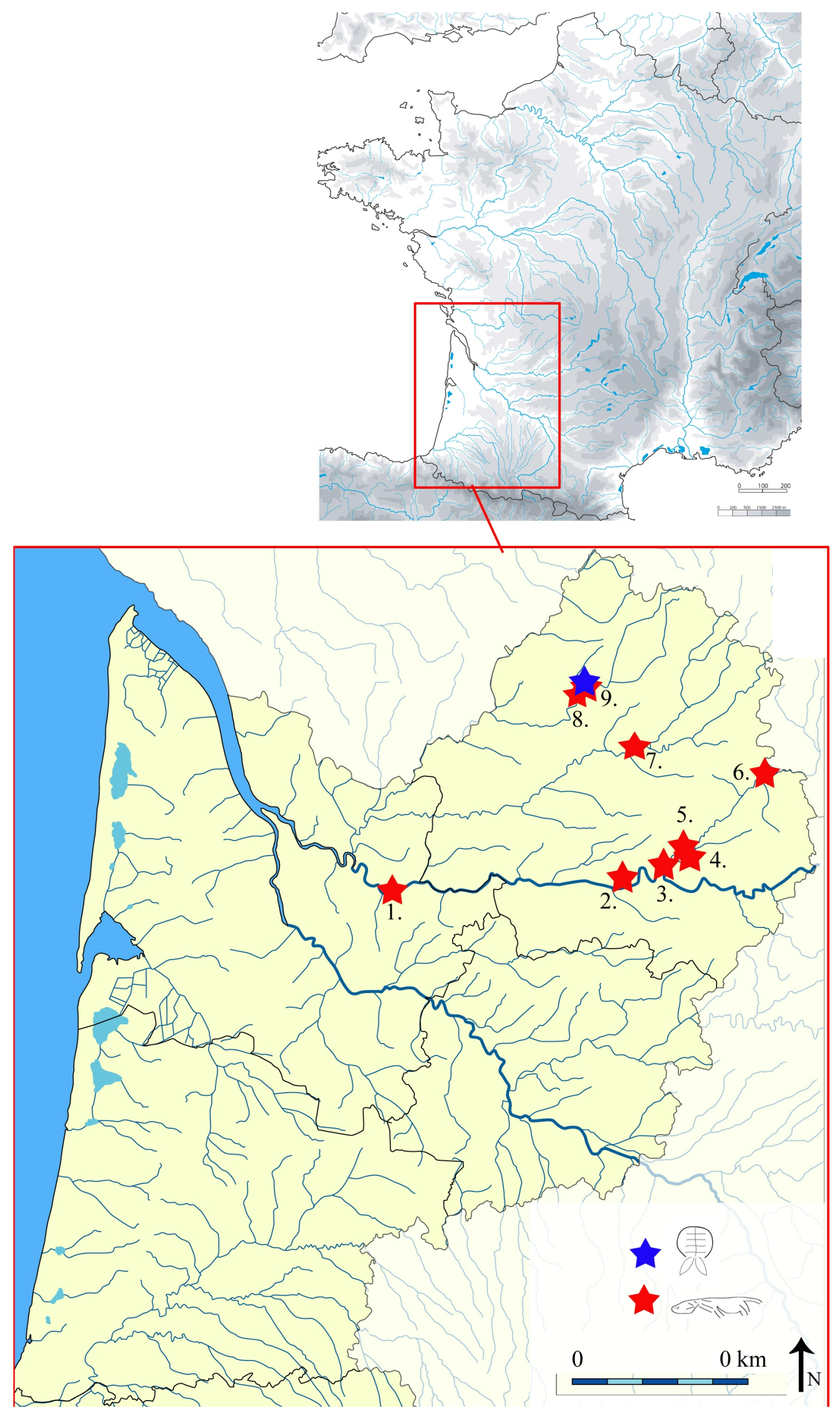



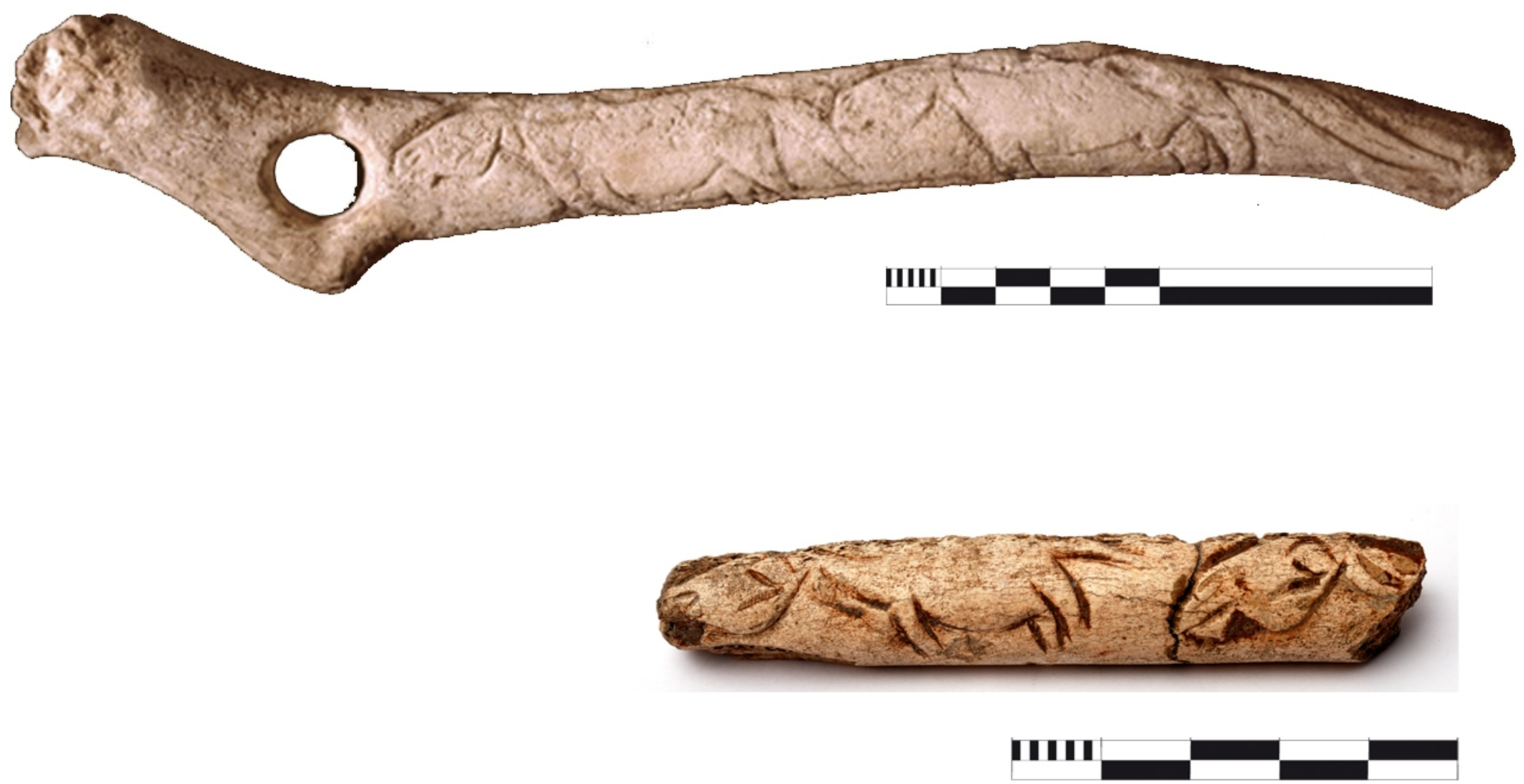


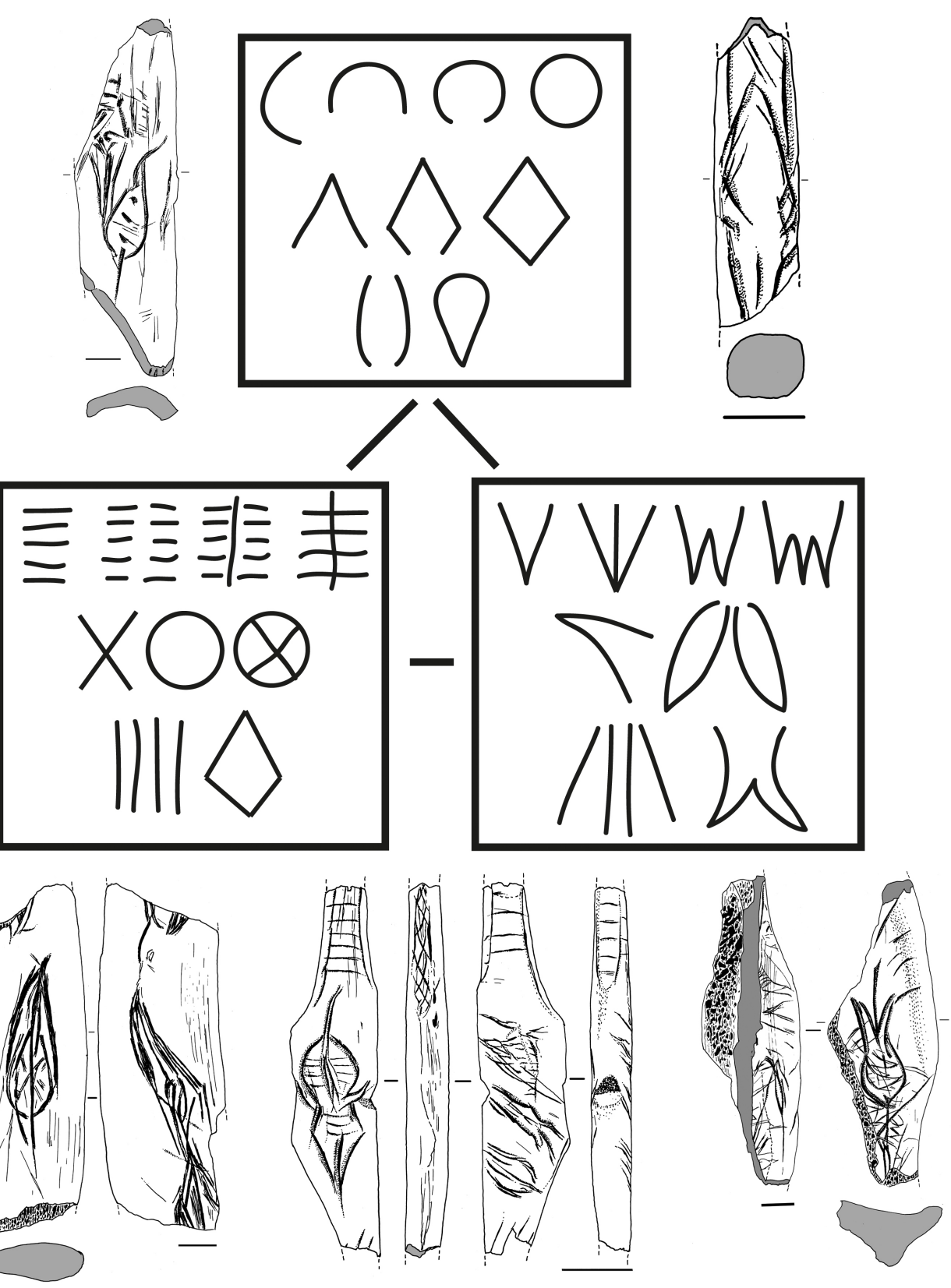

